\title{
AC 2012-4112: SUSTAINABLE ENGINEERING INTERNSHIPS: CREATION AND ASSESSMENT
}

\section{Dr. Yvette Pearson Weatherton, University of Texas, Arlington}

Yvette Pearson Weatherton received her Ph.D. in engineering and applied science (environmental engineering) from the University of New Orleans in 2000. She is currently a Senior Lecturer and Associate Chair of the Department of Civil Engineering at the University of Texas, Arlington, and is a registered Professional Engineer in Louisiana. Pearson Weatherton has served (and continues to serve) as PI or CoPI on several projects funded by the National Science Foundation, including "Engineering Sustainable Engineers," which is the focus of this paper.

Prof. Victoria C. P. Chen, University of Texas, Arlington

Prof. Stephen Mattingly, University of Texas, Arlington

Dr. K.J. Rogers, University of Texas, Arlington

Dr. Melanie L. Sattler, University of Texas, Arlington

Melanie Sattler serves as an Associate Professor at the University of Texas, Arlington, where she teaches courses and conducts research related to air quality and sustainable energy. Her research has been sponsored by the National Science Foundation, Texas Commission on Environmental Quality, Luminant Power, and the Defense Advanced Research Projects Agency. She has published more than 60 peerreviewed papers and conference proceedings. In 2010, she received UT Arlington's Lockheed Martin Excellence in Engineering Teaching Award. She is a registered Professional Engineer in the state of Texas. 


\title{
Sustainable Engineering Internships: Creation and Assessment
}

\begin{abstract}
Engineering Sustainable Engineers, a program sponsored by National Science Foundation (NSF), was designed to improve undergraduate student knowledge of and competency in addressing sustainability issues in engineering design and problem solving. The program involves collaboration among faculty in Civil, Industrial, and Mechanical Engineering at the University of Texas at Arlington. One of the key program elements is placing students in their junior or senior year with companies using exemplary sustainable design and operation practices. The internships expose students to development of solutions that mitigate potential negative impacts on sustainability.
\end{abstract}

To identify companies with exemplary sustainable design and operation practices, the project team created a "Quality Sustainable Engineering Internship Survey” via Survey Monkey, which was sent to over 250 companies that hire engineers in the Dallas-Fort Worth area. The paper will present the survey questions and their rationale, to aid other universities that may want to conduct similar surveys in their own region. Six students were placed in paid internships with the four companies, over two summers. The paper will describe the student-company internship matches that were created. To encourage companies to participate, \$2000 was made available from the NSF grant to support each student's internship

To evaluate the effectiveness of the internships in achieving project objectives, each student completed a survey at the end of his/her internship to assess the impact of the experience. Company representatives also completed a survey, with the goal of collecting information to improve future internship experiences. The paper will summarize survey results.

\section{Introduction}

Sustainability has been identified as one of the global grand challenges of the 21st century. In order for future generations to enjoy a satisfactory quality of life, the current generation must find ways to meet humanity's needs for energy, shelter, food and water in ways that are environmentally, economically, and socially sustainable.

Sustainable engineering may be defined as engineering for human development that meets the needs of the present without compromising the ability of future generations to meet their own needs. ${ }^{1}$ Due to population growth and expanded global development, the next generation of engineers must be able to design with fewer resources for a wider variety and greater number of end users. ${ }^{2}$ According to National Academy of Engineering (NAE) President Charles M. Vest, macroscale issues of great societal importance, like energy, water, and sustainability, will dominate 21st century engineering. ${ }^{3}$ According to the NAE report The Engineer of 2020, engineers of the future must gain a holistic understanding of sustainable economic growth and development, in order to solve society’s pressing environmental problems. ${ }^{4}$ 
To educate undergraduate engineering students about sustainable engineering, and specifically to improve their knowledge of and competency in addressing sustainability issues in engineering design and problem solving, the Engineering Sustainable Engineers program was started at the University of Texas at Arlington, with support from the National Science Foundation. The program involves collaboration among faculty in Civil, Industrial, and Mechanical Engineering. Program elements include:

1. Sustainability Learning Modules, incorporated into 17 undergraduate engineering classes,

2. Multidisciplinary Senior Design Project, and

3. Sustainable Engineering Internships.

The program components, taken collectively, are designed to expose engineering students repeatedly to sustainability concepts during their undergraduate education. Components 1 and 2 are discussed elsewhere. ${ }^{5-9}$ This paper discusses Component 3, Sustainable Engineering Internships.

Sustainable Engineering Internships move the students beyond classroom experiences, exposing them to development of real-world solutions to mitigate negative impacts of engineering designs on sustainability. Students would typically be placed in sustainable engineering internships during their junior or senior year.

\section{Objectives}

The objectives of the work described here were:

1. To develop a survey for identifying companies that would offer a quality sustainable engineering internship,

2. To place students in meaningful internships,

3. To evaluate the effectiveness of the internships.

\section{Methods}

Methods for Identifying Companies. The project team developed a survey that was used to identify companies likely to provide quality sustainable engineering internships. Such companies must incorporate sustainability issues into their design and/or production processes. For example, the existence of a comprehensive waste reduction and recycling program at a company would be commendable, but would not necessarily help an intern learn more about sustainable engineering design. The "Quality Sustainable Engineering Internship Survey,” shown in Figure 1, was created using Survey Monkey. The survey is posted on the project web site at http://www.uta.edu/ce/ese/Internship\%20Options.htm for other universities to use. Motivation behind the survey questions is given in Table 1 . A question that allowed the company to express its preference for a particular engineering major would have added clarity to our survey. 
Figure 1. Quality Sustainable Engineering Internship Survey

\section{Sustainable Internship Company Survey}

\section{Begin your survey}

1. Company Information:

Name of the company:

Email:

Telephone No:

Contact person:

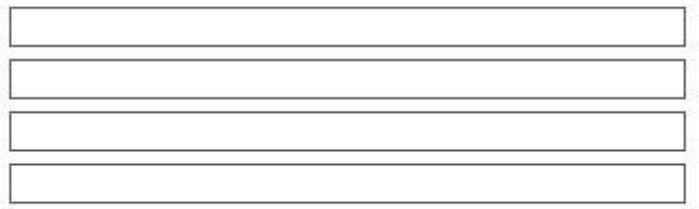

2. Approximately how many employees are employed at your facility?

3. How many employees work full-time in environmental protection at your location?

4. Would your firm accept international students (non-US) for internships?

YES

JO

5. Describe the roles and training that your firm provides to engineering interns, if any.

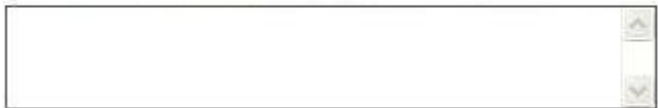

6. Sustainable engineering may be defined as engineering to meet human needs of the present without compromising the ability of future generations to meet their own needs, including environmental protection.

a)Does your current internship program expose students to the development of solutions that mitigate potential negative impacts on sustainability?
YES

NO

7. Refer to question \# 5 , Would your firm consider having this be a goal associated with the student's internship experience?

YES

NO 
Figure 1. Quality Sustainable Engineering Internship Survey (continued)

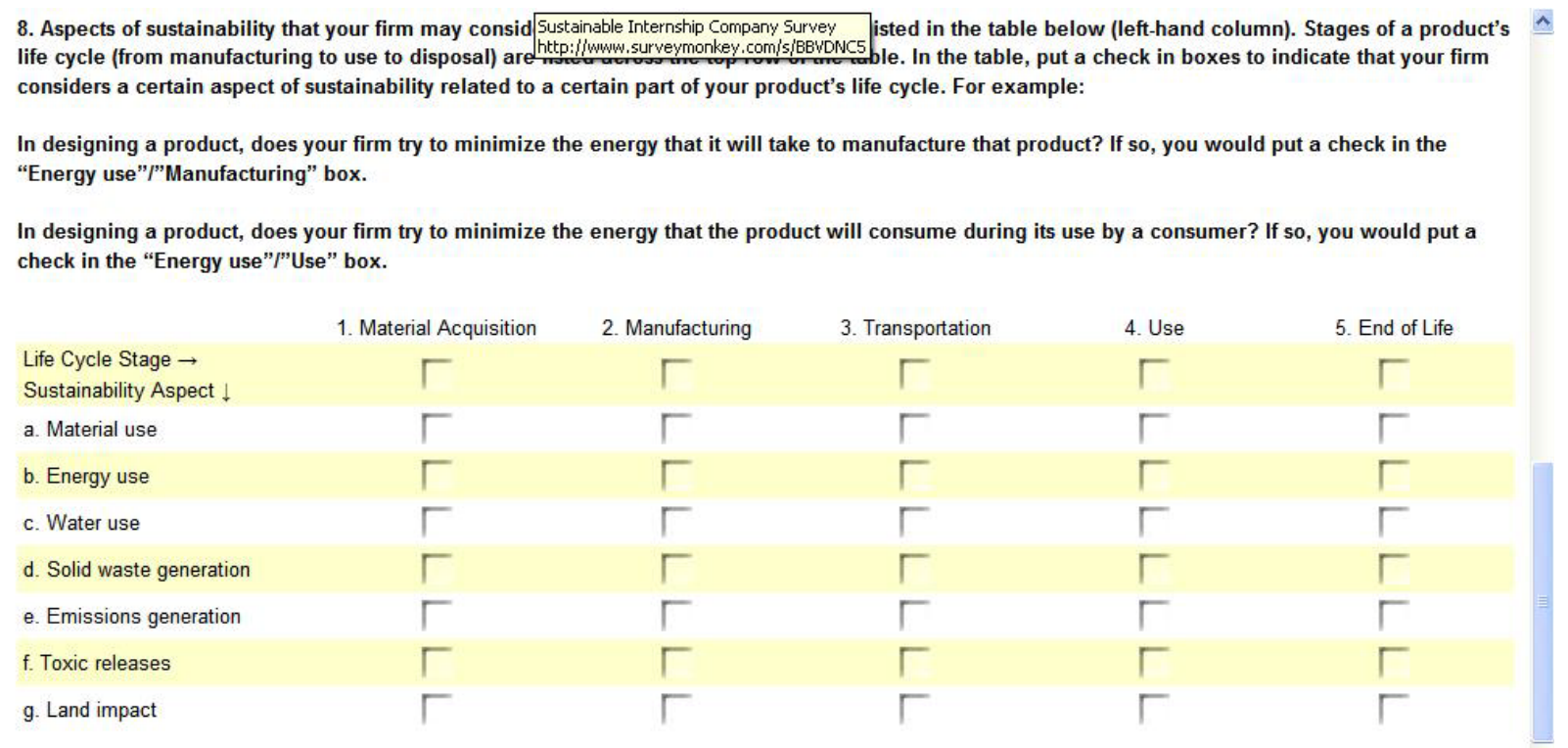

9. Give an example of consideration of sustainability in product design at your firm.

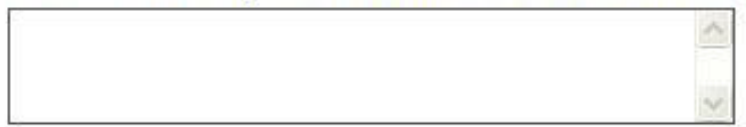

10. Why do you think your firm would be a good choice to sponsor a sustainable engineering internship?

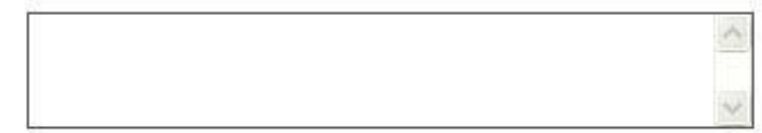


Table 1. Rationale for “Quality Sustainable Internship Survey” Questions

\begin{tabular}{|c|l|}
\hline Question & Motivation \\
\hline 1 & Basic company contact information \\
\hline 2 & Information about whether the company is small or large \\
\hline 3 & $\begin{array}{l}\text { We wanted to know how many employees were engaged in full-time } \\
\text { environmental protection, because we thought that the presence of such } \\
\text { employees would indicate a serious company commitment to sustainability. }\end{array}$ \\
\hline 4 & $\begin{array}{l}\text { Many of our students are international, so opportunities for their } \\
\text { employment would be advantageous. }\end{array}$ \\
\hline 5 & $\begin{array}{l}\text { We were looking for companies that provided interns with meaningful } \\
\text { engineering work, and ideally provided training. }\end{array}$ \\
\hline 8 & $\begin{array}{l}\text { The more metrics of sustainability that a company considers, and the more } \\
\text { life cycle phases that a company considers in design of its } \\
\text { products/structures, the more we would consider that company a model of } \\
\text { exemplary sustainable engineering practice. }\end{array}$ \\
\hline 9 & $\begin{array}{l}\text { Requests a specific example of the general information requested in } \\
\text { Question 8. }\end{array}$ \\
\hline 10 & $\begin{array}{l}\text { Allows companies to provide additional information not already given in } \\
\text { response to another question. }\end{array}$ \\
\hline
\end{tabular}

The university's College of Engineering Internship Coordinator provided the project team a list of over 250 companies that hire engineers in the Dallas/Fort Worth area. An e-mail was sent to the companies inviting them to complete the survey; follow-up phone calls were also placed to several target companies. To encourage companies to participate, \$2000 was made available from the NSF grant to support each student's internship, which the company was then free to supplement.

Methods for Placing Students in Internships. Interested students submitted an internship application explaining their interest in sustainability and how they believed they would benefit from the internship. The application form is available to interested parties from the authors. Internships were publicized via e-mails to students and posting of flyers.

The project team reviewed student applications and identified a short list of top candidates. The applications of these top candidates were then forwarded to the company representatives. Company representatives reviewed the applications, and then conducted phone and in-person interviews with promising candidates. The companies then extended an internship offer to the student of their choice. Hiring was done directly by the company.

Methods for Assessing Internship Effectiveness. Internship effectiveness was assessed via surveys given to participating students and company representatives. Student oral presentations concerning their internship experiences were also evaluated, since improvement in student communication skills was one of the overall project objectives. 


\title{
Results and Discussion
}

\author{
Internship Matches
}

Survey responses and informal follow-up phone interviews were used to select 4 companies with exemplary sustainable design and operation practices to participate in the internship program:

- Kimley-Horn and Associates. This civil engineering consulting firm specializes in land development, transportation, environmental services, and surface water resources. Willing to hire civil engineering interns.

- Facility Performance Associates. This consulting firm specializes in LEED (Leadership in Energy and Environmental Design) project delivery. Willing to hire civil and mechanical engineering interns.

- PepsiCo. The plant that manufactures concentrate used in Pepsi soft drink products is located in Arlington, Texas. Willing to hire industrial and mechanical engineering interns.

- Kroger Manufacturing, Vandervoort Dairy. The plant that packages milk products (e.g. milk, yogurt, cottage cheese) for Kroger grocery stores in Texas is located in Fort Worth, Texas. Willing to hire civil, mechanical, and industrial engineering interns.

The above companies were selected based on their survey responses, which demonstrated that they were actively considering sustainability in their product/facility design and construction/production. They were also willing to hire engineering students in the disciplines participating in the Engineering Sustainable Engineers program.

Following review of student applications and coordination with company representatives, four students were placed in internships with the companies during Summer 2010, as shown in Table 1 below. During Summer 2011, two students were placed in internships. Our NSF proposal stated that we would place at least five students in internships, and we ended up placing six.

Three departments participated in the Engineering Sustainable Engineers program: Civil Engineering, Industrial Engineering, and Mechanical Engineering. We had hoped to place equal number of students from each major in internships, but ended up placing primarily civil engineering students. Several industrial engineering students accepted internships with other companies before being matched in a sustainable engineering internship. We did not have a faculty member actively recruiting students in mechanical engineering, and thus received few mechanical engineering applications.

Table 2 briefly summarizes the nature of the sustainable engineering work that each student performed. The nature of the work that the students performed met our expectations in terms of the students being involved in actual sustainable engineering design and decision-making. 
At the middle of the internship and at the end, each student submitted a report that described their work in more detail, and explained impacts of their projects/designs on sustainability. The PI provided feedback to students concerning the reports. This helped fulfill the project objective of improving student written communication skills. The reports are available from the PI.

Each intern chose a faculty mentor to monitor the internship activities. Mentors were to resolve any conflicts arising between the intern and the company, and to ensure that the intern submits his/her reports. The mentors proved unnecessary, and will not be used again in future programs.

It should be noted that in two cases, the intern's work included an economic evaluation. We were pleased with this, since sustainable solutions should be sustainable not only in terms of the environmental but also in terms of the economy (and society).

Table 2. Sustainable Engineering Internship Matches

\begin{tabular}{|c|c|c|c|c|c|}
\hline Year & Company & Student & $\begin{array}{l}\text { Student's } \\
\text { Major }\end{array}$ & $\begin{array}{l}\text { Nature of Sustainable } \\
\text { Engineering Work }\end{array}$ & $\begin{array}{l}\text { Faculty } \\
\text { Mentor }\end{array}$ \\
\hline 2010 & $\begin{array}{l}\text { Kimley-Horn } \\
\text { and } \\
\text { Associates }\end{array}$ & $\begin{array}{l}\text { Evan } \\
\text { Young }\end{array}$ & $\mathrm{CE}$ & $\begin{array}{l}\text { Development design using } \\
\text { techniques to reduce } \\
\text { stormwater runoff quantity } \\
\text { and improve quality; mixed } \\
\text { use development design }\end{array}$ & $\begin{array}{l}\text { Yvette } \\
\text { Weatherton }\end{array}$ \\
\hline 2010 & $\begin{array}{l}\text { Facility } \\
\text { Performance } \\
\text { Associates }\end{array}$ & $\begin{array}{l}\text { Sandip } \\
\text { Tamrakar }\end{array}$ & $\overline{\mathrm{CE}}$ & $\begin{array}{l}\text { Review of sustainable } \\
\text { building designs for LEED } \\
\text { certification }\end{array}$ & $\begin{array}{l}\text { Melanie } \\
\text { Sattler }\end{array}$ \\
\hline 2010 & PepsiCo & $\begin{array}{l}\text { Amy } \\
\text { Morris }\end{array}$ & IE & $\begin{array}{l}\text { Identification of ways to } \\
\text { change production process to } \\
\text { save water }\end{array}$ & $\begin{array}{l}\text { Jamie } \\
\text { Rogers }\end{array}$ \\
\hline 2010 & $\begin{array}{l}\text { Kroger } \\
\text { Manufacturing } \\
\text { (Vandervoort } \\
\text { Dairy) }\end{array}$ & $\begin{array}{l}\text { Manuela } \\
\text { Arroyo }\end{array}$ & $\mathrm{CE}$ & $\begin{array}{l}\text { Identification of ways to } \\
\text { change production process to } \\
\text { reduce water and energy } \\
\text { consumption. Cost-benefit } \\
\text { analysis of solar power for } \\
\text { one part of production } \\
\text { process. }\end{array}$ & $\begin{array}{l}\text { Yvette } \\
\text { Weatherton }\end{array}$ \\
\hline 2011 & $\begin{array}{l}\text { Facility } \\
\text { Performance } \\
\text { Associates } \\
\end{array}$ & $\begin{array}{l}\text { Sandip } \\
\text { Tamrakar }\end{array}$ & $\mathrm{CE}$ & $\begin{array}{l}\text { Review of sustainable } \\
\text { building designs for LEED } \\
\text { certification }\end{array}$ & $\begin{array}{l}\text { Melanie } \\
\text { Sattler }\end{array}$ \\
\hline 2011 & $\begin{array}{l}\text { Kroger } \\
\text { Manufacturing } \\
\text { (Vandervoort } \\
\text { Dairy) }\end{array}$ & $\begin{array}{l}\text { Amanda } \\
\text { Gentry }\end{array}$ & $\mathrm{CE}$ & $\begin{array}{l}\text { Identification of ways to } \\
\text { facilitate recycling, reduce } \\
\text { water consumption, and } \\
\text { energy consumption, } \\
\text { including economic } \\
\text { evaluation. }\end{array}$ & $\begin{array}{l}\text { Melanie } \\
\text { Sattler }\end{array}$ \\
\hline
\end{tabular}




\section{Internship Assessment: Surveys}

Each student completed a survey at the end of his/her internship to assess the quality of the experience. Multiple-choice survey question responses from students are presented in Table 3.

Table 3. Student Surveys - Sustainable Internship

\begin{tabular}{|c|c|c|c|c|c|}
\hline & Question & $\begin{array}{c}\text { To a } \\
\text { great } \\
\text { extent }\end{array}$ & $\begin{array}{c}\text { To a } \\
\text { moderate } \\
\text { extent }\end{array}$ & $\begin{array}{c}\text { To a } \\
\text { small } \\
\text { extent }\end{array}$ & $\begin{array}{c}\text { Not at } \\
\text { all }\end{array}$ \\
\hline 1 & $\begin{array}{l}\text { The internship increased my ability to explain } \\
\text { sustainability concepts and terminology. }\end{array}$ & $\begin{array}{c}4 \\
67 \%\end{array}$ & $\begin{array}{c}2 \\
33 \%\end{array}$ & $\begin{array}{c}0 \\
0 \%\end{array}$ & $\begin{array}{c}0 \\
0 \%\end{array}$ \\
\hline 2 & $\begin{array}{l}\text { The internship increased my ability to recognize impacts of } \\
\text { engineering project/designs on sustainability. }\end{array}$ & $\begin{array}{c}4 \\
67 \%\end{array}$ & $\begin{array}{c}2 \\
33 \%\end{array}$ & $\begin{array}{c}0 \\
0 \%\end{array}$ & $\begin{array}{c}0 \\
0 \%\end{array}$ \\
\hline 3 & $\begin{array}{l}\text { The internship increased my ability to identify mitigation } \\
\text { strategies for reducing negative impacts on sustainability. }\end{array}$ & $\begin{array}{c}2 \\
33 \%\end{array}$ & $\begin{array}{c}4 \\
67 \%\end{array}$ & $\begin{array}{c}0 \\
0 \%\end{array}$ & $\begin{array}{c}0 \\
0 \%\end{array}$ \\
\hline 4 & $\begin{array}{l}\text { The internship increased my ability to evaluate potential } \\
\text { engineering solutions based on sustainability. }\end{array}$ & $\begin{array}{c}4 \\
67 \% \\
\end{array}$ & $\begin{array}{c}1 \\
17 \%\end{array}$ & $\begin{array}{c}1 \\
17 \%\end{array}$ & $\begin{array}{c}0 \\
0 \%\end{array}$ \\
\hline 5 & $\begin{array}{l}\text { The internship increased my ability to work effectively in } \\
\text { multidisciplinary teams. }\end{array}$ & $\begin{array}{c}4 \\
67 \%\end{array}$ & $\begin{array}{c}2 \\
33 \%\end{array}$ & $\begin{array}{c}0 \\
0 \%\end{array}$ & $\begin{array}{r}0 \\
0 \%\end{array}$ \\
\hline & Question & $\begin{array}{l}\text { Strongly } \\
\text { Agree }\end{array}$ & Agree & Disagree & $\begin{array}{l}\text { Strongly } \\
\text { Disagree }\end{array}$ \\
\hline 6 & $\begin{array}{l}\text { Participation in the internship will make me more likely to } \\
\text { consider sustainable design options in my future career. }\end{array}$ & $\begin{array}{c}5 \\
83 \% \\
\end{array}$ & $\begin{array}{c}1 \\
17 \% \\
\end{array}$ & $\begin{array}{c}0 \\
0 \% \\
\end{array}$ & $\begin{array}{c}0 \\
0 \% \\
\end{array}$ \\
\hline 7 & $\begin{array}{l}\text { I would recommend future students to participate in } \\
\text { sustainable engineering internships. }\end{array}$ & $\begin{array}{c}6 \\
100 \%\end{array}$ & $\begin{array}{c}0 \\
0 \%\end{array}$ & $\begin{array}{c}0 \\
0 \%\end{array}$ & $\begin{array}{c}0 \\
0 \%\end{array}$ \\
\hline & ГAL & $\begin{array}{c}29 \\
69 \%\end{array}$ & $\begin{array}{c}12 \\
29 \%\end{array}$ & $\begin{array}{c}1 \\
2 \%\end{array}$ & $\begin{array}{c}0 \\
0 \%\end{array}$ \\
\hline
\end{tabular}

Student responses to short-answer survey questions are listed below.

\section{What was the best aspect of the sustainable engineering internship?}

- Being able to work in teams with experienced engineers

- Being able to identify areas of improvement and take the initiative to start process improvement

- Being able to understand what sustainability is, and how it impacts consumer products

- Exposure to "real world" applications of coursework

- Working with the engineers of other disciplines; saw how all the engineers work as a team. 
- I got to work on a project that will help reduce water and energy. This will help me a lot in the future when I get to design my own projects. This internship also helped me gain experience in the engineering field.

- $\quad$ Seeing the relationship between business and sustainability. There is a very strong need for sustainability options to be economically sound. This program was great to see this at a hands-on level.

- Working in a multi-disciplinary firm gave me a good idea of how engineering teams work to make new projects sustainable. Hands-on training on available tools to meet today's challenges in making buildings sustainable was most important for me.

\section{What aspect of the sustainable engineering internship needs the most improvement, if it were to be offered again?}

- General outline/guideline for reports

- Rubric for presentation

- More information on the program prior to application

- Communication between other students who are also working as sustainable engineering interns.

- Have students take an environmental class (prior to participating in the internship), because I found that class very useful while I was working.

- Assuring that the company has staff members available to guide interns and assist in developing sustainability options.

Survey responses show that the students feel that the internships increased their ability to explain sustainability concepts, recognize impacts of engineering projects on sustainability, and identify mitigation strategies for reducing negative impacts on sustainability. The internships also increased their ability to work effectively in multidisciplinary teams. Particularly encouraging are the responses that students will be more likely to consider sustainable design options in their future career, with five students strongly agreeing and one student agreeing. All six students strongly agreed that they would recommend the sustainable internships to other students.

Company representatives completed a separate survey, with the goal of collecting information to improve future internship experiences. Multiple-choice survey question responses from company representatives are presented in Table 4. 
Table 4. Company Surveys - Sustainable Internship

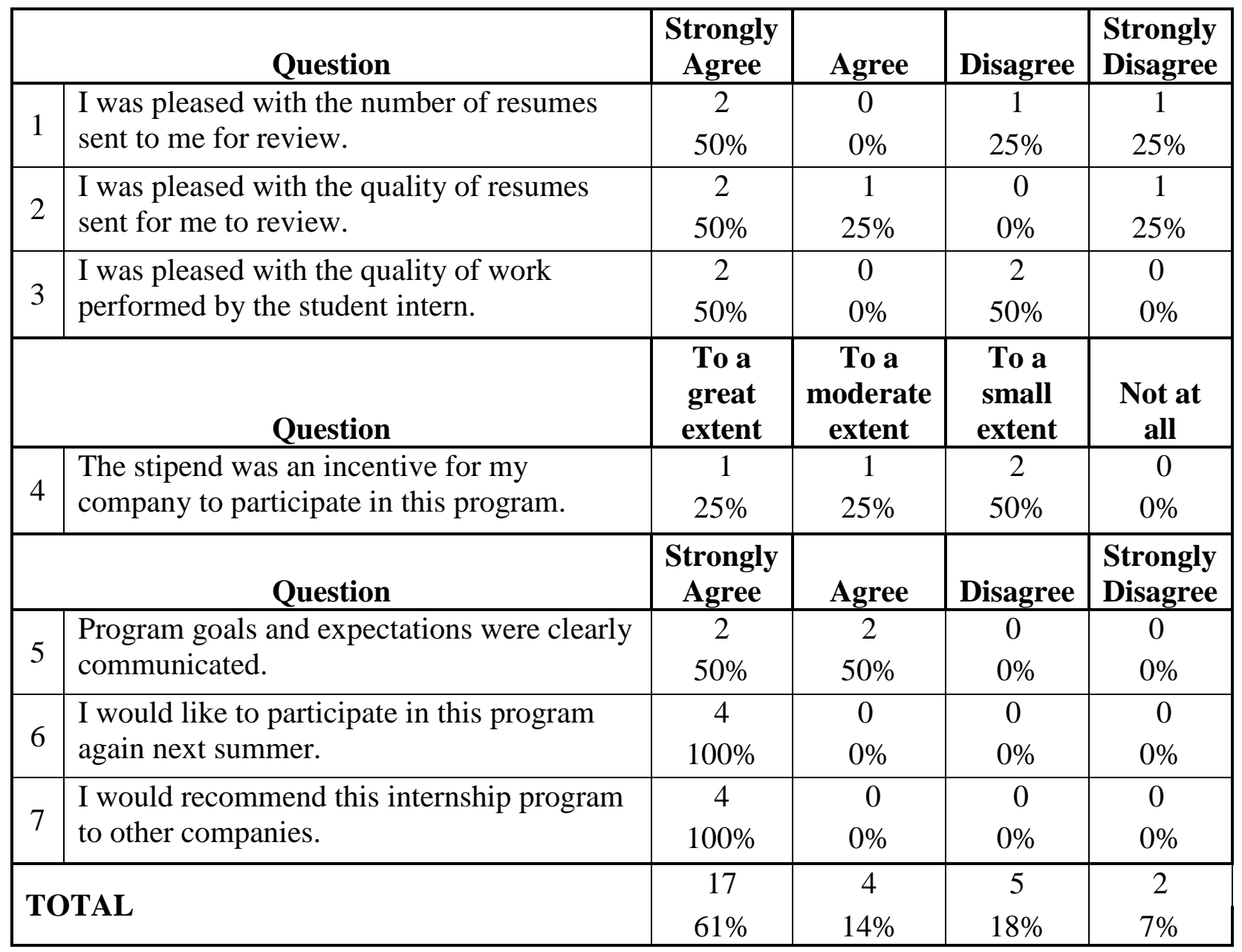

Company representative responses to short-answer survey questions are listed below.

\section{What was the best aspect of the sustainable engineering internship?}

- Opportunity to expose future engineers to a world class sustainability approach and strategy

- Win-win situation, additional person resource semi-qualified for the company/company has the opportunity to instruct and in turn gain fresh ideas forcing us to look at processes differently.

- Help provide valuable experience and exposure to the student; was a symbiotic relationship for the student and company.

- Having the opportunity to bring fresh ideas and young minds into our organization, along with their level of enthusiasm. 


\section{What aspect of the sustainable engineering internship needs the most improvement, if it were to be offered again?}

- Involve company rep in student selection process

- Increase time frame or length of internship

- Look for long-term opportunities for 1-2 year sustainability internships.

- Was done well and appreciated the opportunity to participate. We learned some valuable lessons - would like to participate again so we have an opportunity to grow with the program.

- The student should devote more time to the program and should not be enrolled in summer classes.

- Would like milestone surveys sent directly to the employer instead of going through the student. Also, copies of the reports the students complete.

The fact that all companies want to participate in the program again and would recommend the program to other companies is positive. The company survey responses offer helpful ideas for improvement of future internship programs. One company was not satisfied with their student's performance; this student was taking classes in addition to pursuing the internship, which meant less than full-time work on the internship. In the future, we will specify during the application process that the internship is a full-time commitment.

Our hope is that these initial internships will initiate long-term partnerships that will enable the internship program to continue. In this vein, we plan scheduled a tour of the Kroger Manufacturing facility during the fall semester for members of the UT Arlington student chapter of the Air \& Waste Management Association.

\section{Internship Assessment: Student Presentations}

One of the objectives of the overall Engineering Sustainable Engineers program was improving student communication skills. To help achieve this objective, students participating in an internship were given the opportunity to give and receive feedback on an oral presentation. At the end of each summer, a seminar was held, at which each student presented one of his/her reports. Students, company representatives, and faculty mentors attended the seminar, and used a rubric to assess the student presentations.

Results from these assessments are provided in Table 5. We feel that the student presentations were acceptable, especially considering that this may have been the first opportunity to give a presentation for some of the students. According to the data in Table 5, the following areas had more than $20 \%$ of responses as neutral or disagree, indicating particular room for improvement in the presentations:

- Demonstrating that student could use sustainability as a criteria in choosing among engineering alternatives.

- Using gestures where appropriate. 
In addition, avoiding use of filler words like "um" had the least number of "strongly agree" responses, indicating another area for improvement. One strategy for improving future student presentations will be to provide students with the rubric ahead of time, to give them ideas about what makes for good presentation content and communication effectiveness.

Table 5. Evaluation of Student Internship Presentations

\begin{tabular}{|c|c|c|c|c|c|c|}
\hline \multicolumn{2}{|r|}{ Questions - Presentation Content } & $\begin{array}{c}\text { Strongly } \\
\text { Agree }\end{array}$ & Agree & Neutral & Disagree & $\begin{array}{l}\text { Strongly } \\
\text { Disagree }\end{array}$ \\
\hline 1 & $\begin{array}{l}\text { The presentation demonstrated that student } \\
\text { could recognize potential negative impacts of } \\
\text { engineering designs on sustainability. }\end{array}$ & $\begin{array}{c}17 \\
38 \%\end{array}$ & $\begin{array}{c}22 \\
49 \%\end{array}$ & $\begin{array}{c}3 \\
7 \%\end{array}$ & $\begin{array}{c}3 \\
7 \%\end{array}$ & $\begin{array}{c}0 \\
0 \%\end{array}$ \\
\hline 2 & $\begin{array}{l}\text { The presentation demonstrated that student } \\
\text { could identify ways to mitigate potential } \\
\text { negative impacts on sustainability. }\end{array}$ & $\begin{array}{c}17 \\
38 \%\end{array}$ & $\begin{array}{c}26 \\
58 \%\end{array}$ & $\begin{array}{c}1 \\
2 \%\end{array}$ & $\begin{array}{c}1 \\
2 \%\end{array}$ & $\begin{array}{c}0 \\
0 \%\end{array}$ \\
\hline 3 & $\begin{array}{l}\text { The presentation demonstrated that student } \\
\text { could use sustainability as a criteria in choosing } \\
\text { among engineering alternatives. }\end{array}$ & $\begin{array}{c}18 \\
40 \%\end{array}$ & $\begin{array}{c}17 \\
38 \%\end{array}$ & $\begin{array}{c}7 \\
16 \%\end{array}$ & $\begin{array}{c}3 \\
7 \%\end{array}$ & $\begin{array}{c}0 \\
0 \%\end{array}$ \\
\hline 4 & $\begin{array}{l}\text { The presentation contained an appropriate } \\
\text { introduction. }\end{array}$ & $\begin{array}{c}20 \\
45 \%\end{array}$ & $\begin{array}{c}18 \\
41 \%\end{array}$ & $\begin{array}{c}5 \\
11 \%\end{array}$ & $\begin{array}{c}1 \\
2 \%\end{array}$ & $\begin{array}{c}0 \\
0 \%\end{array}$ \\
\hline 5 & The presentation was well-organized. & $\begin{array}{c}19 \\
42 \% \\
\end{array}$ & $\begin{array}{c}21 \\
47 \% \\
\end{array}$ & $\begin{array}{c}3 \\
7 \% \\
\end{array}$ & $\begin{array}{c}2 \\
4 \% \\
\end{array}$ & $\begin{array}{c}0 \\
0 \% \\
\end{array}$ \\
\hline 6 & $\begin{array}{l}\text { The presentation contained an appropriate } \\
\text { conclusion. }\end{array}$ & $\begin{array}{c}16 \\
36 \%\end{array}$ & $\begin{array}{c}21 \\
47 \%\end{array}$ & $\begin{array}{c}5 \\
11 \%\end{array}$ & $\begin{array}{c}3 \\
7 \%\end{array}$ & $\begin{array}{c}0 \\
0 \%\end{array}$ \\
\hline & Questions - Communication Effectiveness & $\begin{array}{l}\text { Strongly } \\
\text { Agree }\end{array}$ & Agree & Neutral & Disagree & $\begin{array}{l}\text { Strongly } \\
\text { Disagree }\end{array}$ \\
\hline 7 & $\begin{array}{l}\text { The format of the PowerPoint slides was clear } \\
\text { and easy to read. }\end{array}$ & $\begin{array}{c}23 \\
51 \% \\
\end{array}$ & $\begin{array}{c}19 \\
42 \% \\
\end{array}$ & $\begin{array}{c}2 \\
4 \% \\
\end{array}$ & $\begin{array}{c}1 \\
2 \% \\
\end{array}$ & $\begin{array}{c}0 \\
0 \% \\
\end{array}$ \\
\hline 8 & The student spoke loudly enough. & $\begin{array}{c}24 \\
53 \% \\
\end{array}$ & $\begin{array}{c}19 \\
42 \% \\
\end{array}$ & $\begin{array}{c}2 \\
4 \% \\
\end{array}$ & $\begin{array}{c}0 \\
0 \% \\
\end{array}$ & $\begin{array}{c}0 \\
0 \% \\
\end{array}$ \\
\hline 9 & $\begin{array}{l}\text { The student spoke at an appropriate pace (not } \\
\text { too fast or too slow). }\end{array}$ & $\begin{array}{c}22 \\
49 \% \\
\end{array}$ & $\begin{array}{c}22 \\
49 \% \\
\end{array}$ & $\begin{array}{c}1 \\
2 \% \\
\end{array}$ & $\begin{array}{c}0 \\
0 \% \\
\end{array}$ & $\begin{array}{c}0 \\
0 \% \\
\end{array}$ \\
\hline 10 & $\begin{array}{l}\text { The student made sufficient eye contact with the } \\
\text { audience. }\end{array}$ & $\begin{array}{c}24 \\
55 \% \\
\end{array}$ & $\begin{array}{c}15 \\
34 \% \\
\end{array}$ & $\begin{array}{c}3 \\
7 \% \\
\end{array}$ & $\begin{array}{c}2 \\
5 \% \\
\end{array}$ & $\begin{array}{c}0 \\
0 \% \\
\end{array}$ \\
\hline 11 & $\begin{array}{l}\text { The student avoided using filler words like } \\
\text { "um". }\end{array}$ & $\begin{array}{c}12 \\
27 \% \\
\end{array}$ & $\begin{array}{c}27 \\
60 \% \\
\end{array}$ & $\begin{array}{c}3 \\
7 \% \\
\end{array}$ & $\begin{array}{c}3 \\
7 \% \\
\end{array}$ & $\begin{array}{c}0 \\
0 \% \\
\end{array}$ \\
\hline 12 & $\begin{array}{l}\text { The student avoided simply reading text from } \\
\text { the slides, but instead explained material. }\end{array}$ & $\begin{array}{c}23 \\
51 \% \\
\end{array}$ & $\begin{array}{c}15 \\
33 \% \\
\end{array}$ & $\begin{array}{c}5 \\
11 \% \\
\end{array}$ & $\begin{array}{c}2 \\
4 \% \\
\end{array}$ & $\begin{array}{c}0 \\
0 \% \\
\end{array}$ \\
\hline 13 & The student used gestures where appropriate. & $\begin{array}{c}14 \\
31 \% \\
\end{array}$ & $\begin{array}{c}20 \\
44 \% \\
\end{array}$ & $\begin{array}{c}9 \\
20 \% \\
\end{array}$ & $\begin{array}{c}2 \\
4 \% \\
\end{array}$ & $\begin{array}{c}0 \\
0 \% \\
\end{array}$ \\
\hline TO & TAL & $\begin{array}{l}249 \\
43 \%\end{array}$ & $\begin{array}{c}262 \\
45 \%\end{array}$ & $\begin{array}{c}49 \\
8 \%\end{array}$ & $\begin{array}{l}23 \\
4 \%\end{array}$ & $\begin{array}{c}0 \\
0 \%\end{array}$ \\
\hline
\end{tabular}




\section{Conclusions}

A “Quality Sustainable Engineering Internship Survey” was created via Survey Monkey and used to identify four companies with exemplary sustainable design and operation practices. Six students were placed in internships with the four companies, over two summers. The nature of the work that the students performed met our expectations in terms of the students being involved in actual sustainable engineering design and decision-making. Survey responses show that the students feel that the internships increased their ability to explain sustainability concepts, recognize impacts of engineering projects on sustainability, and identify mitigation strategies for reducing negative impacts on sustainability. The fact that all companies want to participate in the program again and would recommend the program to other companies is positive. Our hope is that these initial internships will initiate long-term partnerships that will enable the internship program to continue.

\section{Acknowledgments}

We acknowledge the National Science Foundation Engineering Education Program for funding this research through Innovations in Engineering Education, Curriculum, and Infrastructure (IEECI) grant (Award number 0935202).

\section{Bibliography}

1. World Commission on Environment and Development. Our Common Future, Oxford University Press, 1987.

2. Davidson, Cliff I.; Matthews, H. Scott; Hendrickson, Chris T.; Bridges, Michael W.; Allenby, Braden R.; Crittenden, John C.; Chen, Yongsheng; Williams, Eric; Allen David T.; Murphy, Cynthia F.; and Sharon Austin. "Adding Sustainability to the Engineer's Toolbox: A Challenge for Engineering Educators.” Environmental Science \& Technology, 2007, pp. 4847-4850

3. Vest, Charles. “Context and Challenge for Twenty-First Century Engineering Education.” Journal of Engineering Education, July 2008, pp. 235-236.

4. National Academy of Engineering. The Engineer of 2020: Visions of Engineering in the New Century. National Academies Press, Washington, D.C., 2004.

5. Sattler, Melanie; Chen, Victoria; Dennis, Brian H.; Mattingly, Stephen; Rogers, K. Jamie; Weatherton, Yvette Pearson. "Integrating Sustainability Across the Curriculum: Engineering Sustainable Engineers," Accepted for the American Society for Engineering Education, 2012 Annual Conference and Exposition, San Antonio, Texas, June 2012.

6. Mattingly, Stephen; Chen, Victoria; Dennis, Brian H.; Rogers, K. Jamie; Sattler, Melanie; Weatherton, Yvette Pearson. "Multi-Disciplinary Sustainable Senior Design Project: Design of a Campus Biodiesel Refinery," Accepted for the American Society for Engineering Education, 2012 Annual Conference and Exposition, San Antonio, Texas, June 2012.

7. Rogers, K. Jamie; Sattler, Melanie. "Life Cycle Sustainability Economics.” Accepted for the American Society for Engineering Education, 2012 Annual Conference and Exposition, San Antonio, Texas, June 2012. 
8. Chen, Victoria; Rogers, K. Jamie; Mattingly, Stephen; Sattler, Melanie; Weatherton, Yvette Pearson. "Sustainable Industrial Engineering Modules.” Accepted for the American Society for Engineering Education, 2012 Annual Conference and Exposition, San Antonio, Texas, June 2012.

9. Sattler, Melanie; Weatherton, Yvette. "Engineering Sustainable Civil Engineers.” American Society for Engineering Education, 2011 Annual Conference and Exposition, Vancouver, B.C., Canada, June 26-29, 2011. 